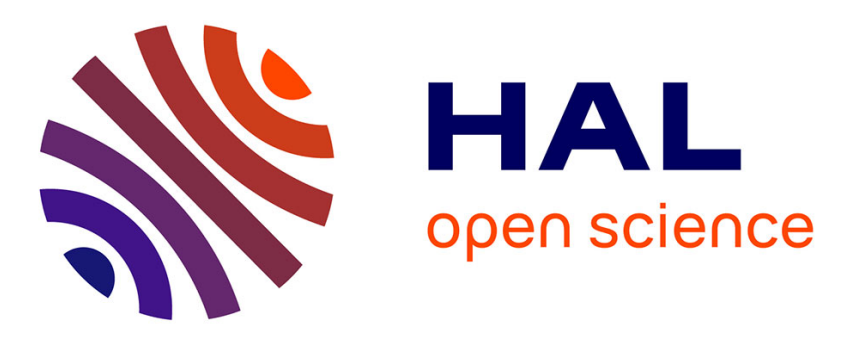

\title{
Influence of organic matter properties on porosity of kimmeridge clay source rocks during laboratory thermal maturation.
}

\author{
Amélie Cavelan, Mohammed Boussafir, Claude Le Milbeau, Sandrine \\ Delpeux, Olivier Rozenbaum, Fatima Laggoun-Défarge
}

\section{To cite this version:}

Amélie Cavelan, Mohammed Boussafir, Claude Le Milbeau, Sandrine Delpeux, Olivier Rozenbaum, et al.. Influence of organic matter properties on porosity of kimmeridge clay source rocks during laboratory thermal maturation.. 29th International Meeting on Organic Geochemistry (IMOG), Sep 2019, Gothenburg, Sweden. p1- 2. hal-03169772

\section{HAL Id: hal-03169772 \\ https://hal.science/hal-03169772}

Submitted on 15 Mar 2021

HAL is a multi-disciplinary open access archive for the deposit and dissemination of scientific research documents, whether they are published or not. The documents may come from teaching and research institutions in France or abroad, or from public or private research centers.
L'archive ouverte pluridisciplinaire HAL, est destinée au dépôt et à la diffusion de documents scientifiques de niveau recherche, publiés ou non, émanant des établissements d'enseignement et de recherche français ou étrangers, des laboratoires publics ou privés. 


\title{
INFLUENCE OF ORGANIC MATTER PROPERTIES ON POROSITY OF KIMMERIDGE CLAY SOURCE ROCKS DURING LABORATORY THERMAL MATURATION.
}

\author{
A. Cavelan ${ }^{1}$, M. Boussafir ${ }^{1}$, C. Le Milbeau ${ }^{1}$, S. Delpeux ${ }^{2}$, O. Rozenbaum ${ }^{3}$, F. Laggoun- \\ Défarge ${ }^{1}$. \\ ${ }^{1}$ : Institut des Sciences de la Terre d'Orléans, France. \\ 2 : ICMN, France \\ 3: CEMHTI, France
}

Thermal maturation of organic matter (OM) and the ensuing generation of oil, gas and organic rich residues appear to be the major factor controlling the development, the size and the abundance of OM pores in marine organic-rich mudstones (Katz and Arango, 2018; Ko et al., 2018). However, different formations containing a similar type II OM can exhibit different OM pore evolution models indicating that other factors, such as maceral composition, may influence the evolution of OM porosity during burial (Ko et al., 2018). To investigate how the chemical properties of the total particulate OM assemblage affect the evolution of porosity during thermal diagenesis of organic-rich marine mudstones, laboratory gold-tube anhydrous confined thermal maturation $\left(325^{\circ} \mathrm{C}-470^{\circ} \mathrm{C}\right.$ for $\left.72 \mathrm{~h}\right)$ was applied on immature Kimmeridge Clay (KCF) mudstones (Yorkshire, UK) which contain a type II oil-prone kerogen (HI: 418 to $617 \mathrm{mg} \mathrm{HC} / \mathrm{g}$ TOC). The evolution of pore volume and pore size distribution was calculated using nitrogen adsorption measurement and evaluated as a function of OM properties: palynofacies analysis, Rock Eval $6{ }^{\circledR}$ pyrolysis, the amount and the composition of oil and gas generated during maturation (GC-TCD and GC/MS analysis). The addressed question is to know how slight differences in the relative proportion of individual OM components throughout a same formation influence OM chemical transformations and pore development during thermal maturation of organic-rich marine mudstones.

The results show that two organic rich KCF samples (TOC $=10.3$ and $14.4 \mathrm{wt} . \%$ respectively), M1 and M2, with different particulate OM assemblage can exhibit different OM pore evolution during thermal maturation, especially in the gas window (Figure 1). M1 contain higher proportion of brown amorphous organic matter (AOM) derived from cell walls of microalgae. M2 contains mainly oil-prone phytoplanktonic OM preserved by natural sulfurization, which gives it slightly higher sterane, hopane and monoaromatic steroid concentrations and higher oil and gas generation potential (Figure 1A). M2 OM conversion has, indeed led to the production of higher amount of low viscous oil (S1, SAT+ARO, Figure 1A) and abundant gaseous hydrocarbon concentrations more favourable to the formation of abundant but small OM hosted micropores and mesopores (Figure 1B). Meanwhile, the secondary cracking of the heavier and more viscous oil produced by brown-AOM-rich OM (M1) led to formation of greater quantity of $\mathrm{CO}_{2}$ (Figure 1A) and an abundant organic-rich residue more favorable to the formation of fewer but larger mesopores (Figure 1B). In the dry gas zone, M2 micro and mesopores have coalesced in response of $\mathrm{CH}_{4}$ generation to form larger mesopores and macropores (Figure 1B). This phenomenon has surprisingly not conducted to the increase of M2 pore volume which remains relatively low contrary to M1 (Figure 1A). Despite their slightly higher oil-prone quality, samples containing higher amount of orange AOM seems less favorable to the formation of larges mesopores and important pore volume during thermal maturation (M2, Figure 1). Thus, a higher potential for oil and gas generation do not lead systematically to the formation of a greater pore volume in OM during maturation. This suggests that slight variations of the individual particulate $\mathrm{OM}$ assemblage of a similar type II kerogen throughout a same formation can significantly influence the composition and the amount of oil and gas 
generated during thermal maturation resulting in different $\mathrm{OM}$ pore development and evolution.

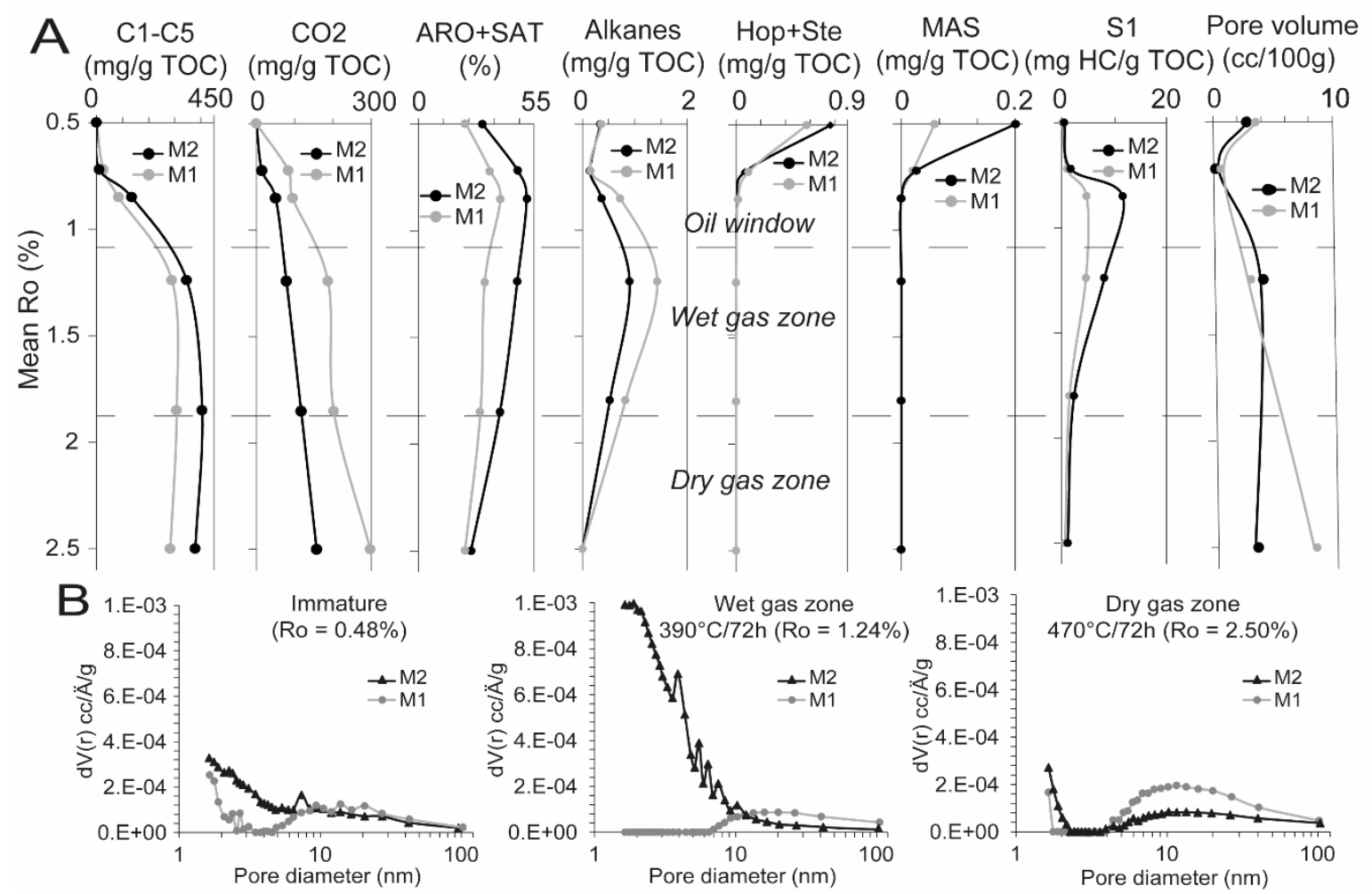

Figure 1 A) Evolution of pore volume, S1, concentrations of monoaromatic steroids (MAS), hopanes and steranes (Hop+Ste), alkanes (including isoprenoids), gas (methane to pentane, $C O 2)$, relative proportion of aromatic $(A R O)$ and saturated hydrocarbons $(S A T)$ and $B)$ pore size distribution during thermal maturation of two KCF mudstones.

Moreover, we can assume that the shorter duration and the higher temperature of our laboratory experiments may have limited the OM chemical transformations compared to natural systems. This may affect differently orange and brown AOM explaining some of the differences between samples such as the surprising low pore volumes and alkane concentrations of M2 (Figure 1A). Comparison of these results with longer duration laboratory experiments may lead to a better understanding of the influence of these processes on OM pore development. Nevertheless, these results put forward the necessity to consider both the level of maturity and the composition of the original particulate OM assemblage to better predict the composition and the amount of oil and gas generated during maturation and the associated pore evolution model.

\section{References}

Katz and Arango, 2018. Organic porosity: A geochemist's view of the current state of understanding. Organic Geochemistry 123, pp. 1-16.

Ko et al., 2018. Pore-types and pore-network evolution in Upper Devonian-Lower Mississippian Woodford and Mississippian Barnett mudstones: Insights from laboratory thermal maturation and organic petrology. International Journal of Coal Geology 190, pp. 3-28. 